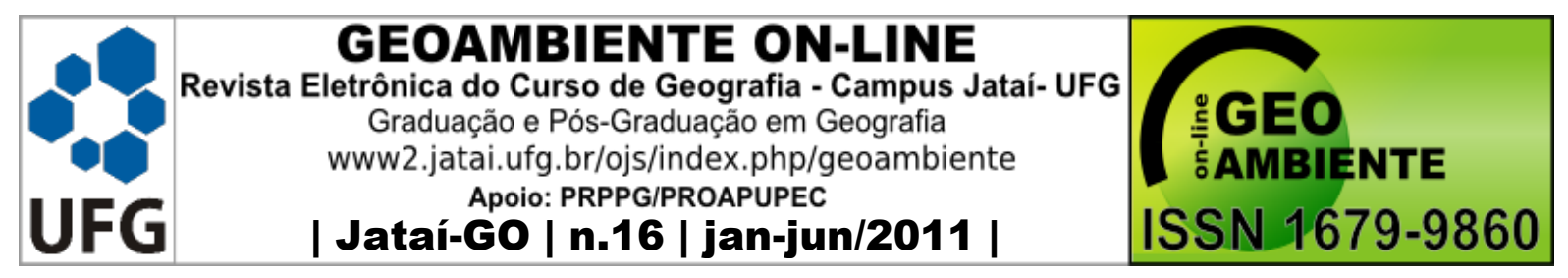

\title{
ANALISE DO MICROCLIMA EM CUIABÁ-MT: UM ESTUDO DE CASO NOS BAIRROS DUQUE DE CAXIAS E DOS BANDEIRANTES ${ }^{1}$
}

\author{
Laura Cristina da Silva Vasconcelos ${ }^{2}$ \\ Cleusa Aparecida Gonçalves Pereira Zamparoni ${ }^{3}$
}

(2 - Universidade Federal de Mato Grosso. Profa. MSc. do Departamento de Geografia, Membro do Grupo de Estudos TROPCLIM/CNPq. E-mail: lauravasconcelo@yahoo.com.br. 3 - Universidade Federal de Mato Grosso. Profa. Dra. do Departamento de Geografia. Líder do Grupo de Estudos TROPCLIM/CNPq. E-mail: cazamp@terra.com.br)

\section{Resumo:}

Os efeitos da urbanização no ambiente se intensificaram após a Revolução Industrial, comprometendo a qualidade ambiental e de vida humana. Isto pode ser comprovado através das pesquisas realizadas que têm demonstrado que a urbanização afeta o clima em escala micro e meso. Assim o objetivo foi comparar os dados climatológicos coletados nos bairros Duque de Caxias e dos Bandeirantes, localizados em Cuiabá - MT. Para isso, foi instalado uma estação climatológica em cada bairro, nas quais utilizou-se as seguintes variáveis: temperatura média do ar, umidade relativa média do ar, precipitação total diária e direção do vento, para colaborar no estudo foi analisada a circulação regional fornecida por imagens de satélites e cartas sinóticas fornecidas pelo INPE. Sendo que os dados foram referentes a uma semana no mês de janeiro de 2007 e uma semana no mês de julho de 2007. Ao analisar os dados observou-se que a estação Duque de Caxias encontra-se instalada numa área pouco urbanizada e próxima a áreas verdes. Já a dos Bandeirantes está localizada num bairro próximo ao centro principal da cidade. Desta forma, esta apresentou maiores taxas de temperatura do ar e menor de umidade relativa, tanto na estação chuvosa como na seca. $\mathrm{Na}$ estação chuvosa a diferença foi de: temperatura do ar: $0,6^{\circ} \mathrm{C}$; umidade relativa do ar: $3,4 \%$; já na estação seca: temperatura do ar: $0,7^{\circ} \mathrm{C}$; umidade relativa do ar: $5,3 \%$. Dessa forma, percebe-se a importância de áreas verdes para o microclima, e sociedade e governo possuem papel importante na manutenção do meio ambiente.

\footnotetext{
Artigo recebido para publicação em 01 de Setembro de 2010

Artigo aprovado para publicação em 08 de Junho de 2011

${ }^{1}$ Parte do Trabalho de Conclusão de Curso apresentado ao Curso de Geografia da Universidade Federal de Mato Grosso
} 


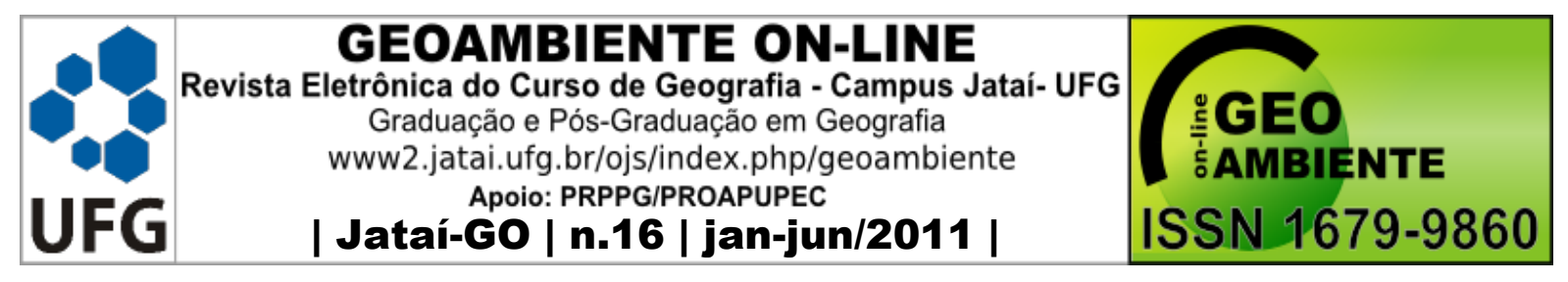

Palavras-chaves: Microclima, urbanização, Cuiabá.

\section{Abstract \\ ANALYSIS OF THE MICROCLIMATE IN CUIABÁ - MT: A CASE STUDY IN THE DISTRICTS OF DUQUE DE CAXIAS AND BANDEIRANTES}

The effects of urbanization in the environment have intensified since the Industrial Revolution, compromising not only the environment but also human life. This can be verified through research that has shown that urbanization affects the climate at micro and medium levels. Thus, the objective of this study was to compare the climatological data collected in the districts of Duque de Caxias and Bandeirantes, both in Cuiabá-MT. For this, in each district a climatological station was installed in which the following variables were used: medium air temperature, medium relative air humidity, total daily precipitation, and wind direction. To help in the study, the regional circulation given by satellite images and synoptic charts furnished by INPE (National Space Research Institute) were analyzed. The data referred to one week in the month of January, 2007 and one week in the month of July, 2007. Through the data it was possible to observe that the Duque de Caxias station is positioned in a less urbanized area, close to more vegetation. On the other hand, the Bandeirantes station is installed in a district close to the center of the city. Thus, it presented higher rates of air temperature and lower relative humidity, both in the wet and in the dry season. In the rainy season the difference was: in the air temperature: $0,6^{\circ} \mathrm{C}$; relative air humidity: $3,4 \%$; in the dry season: air temperature: $0,7^{\circ} \mathrm{C}$; relative air humidity: $5,3 \%$. In this way, the importance of green areas for the micro-climate, can be perceived and society, and government have an important role in the maintenance of the environment.

Key words: Microclimate, urbanization, Cuiabá.

\section{Resumen}

\section{ANÁLISIS DEL MICROCLIMA EN CUIABÁ-BRASIL: UN ESTUDIO DE CASO EN LOS BARRIO DUQUE DE CAXIAS Y BANDEIRANTES}

Los efectos de la urbanización sobre el medio ambiente se intensificó después de la Revolución Industrial, comprometiéndose la calidad del medio ambiente y de la vida humana. Esto puede ser demostrado a través de las investigaciones que la urbanización afecta el clima en escala micro y meso. El objetivo del articulo fue comparar los datos climáticos recogidos 


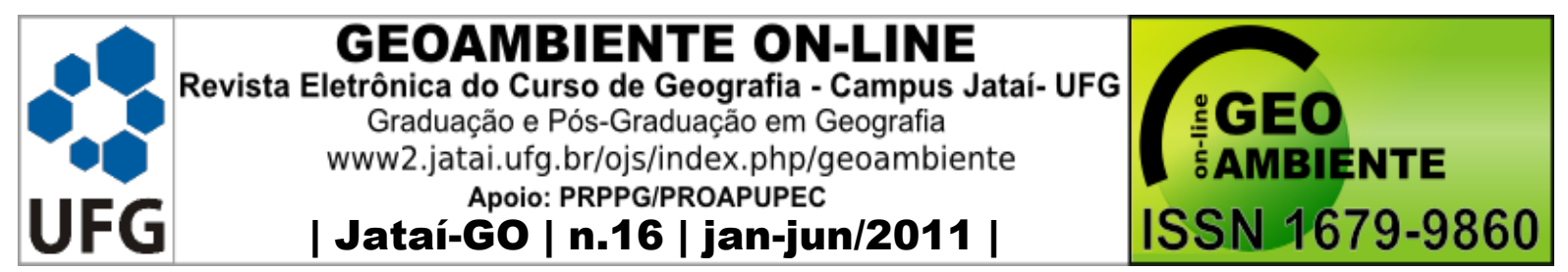

en los barrios Duque de Caxias y Bandeirantes, que se encuentra en Cuiabá - MT. Estaciónes meteorológicas fueran instalada en los barrios, evaluandose las siguientes variables: temperatura media del aire, humedad relativa del aire, el total de precipitación diaria y la dirección del viento, para colaborar en el estudio se analizó la circulación regional a traves de las imágenes de satélites y mapas sinópticos proporcionada por el INPE. Los datos corresponden a una semana de enero de 2007 y una semana de julio de 2007. Análisis de los datos mostró que ela estación de Duque de Caxias se encuentra en una zona de pequeña urbanización y cerca de zonas verde. La estación Bandeirantes ya se encuentra en un barrio cerca del centro de la ciudad. Por lo tanto, este mostró tasas más altas de la temperatura del aire y menor humedad relativa, tanto en la época de lluvias como de sequía. En la temporada de lluvias la diferencia fue de: temperatura del aire: $0,6^{\circ} \mathrm{C}$, humedad relativa del 3,4\%, mientras que en la época seca, la temperatura del aire: $0,7^{\circ} \mathrm{C}$, humedad relativa del 5,3\%. Así, vemos la importancia de las áreas verdes para el microclima, siendo que el gobierno y la sociedad tienen un papel importante en el sostenimiento del medio ambiente.

Palabras clave: Microclima, urbanización, Cuiabá.

\section{1 - Introdução}

Pode-se afirmar que os efeitos da urbanização no ambiente se intensificaram após a Revolução Industrial, comprometendo a qualidade ambiental e a vida humana. Este período histórico trouxe em seu bojo um grande crescimento demográfico e centralização das atividades comerciais, financeiras, institucionais, industriais, entre outras. Tudo isso proporcionou uma valorização do espaço urbano e, consequentemente, o crescimento urbano.

Segundo Buccheri Filho; Nucci (2006), o crescimento ininterrupto das áreas urbanizadas vem incentivando as alterações na paisagem. $\mathrm{O}$ resultado implica na qualidade do meio físico. Lefebvre (1969 apud BUCCHERI FILHO; NUCCI, op. cit.) complementam que cada vez mais, as necessidades humanas (alimento, local para dormir, pessoas para interagir, ar fresco, água potável, etc.) são consideradas luxos e para consegui-las desenvolvem uma intensa luta.

Neste sentido remove-se a vegetação para dar lugar às edificações e superfícies pavimentadas que prejudica o meio ambiente, pois a arborização proporciona equilíbrio ao clima, uma vez que interfere na temperatura, na velocidade dos ventos, na pluviosidade, balanço de energia, balanço de radiação, etc. Desta forma nos últimos anos tem se verificado 


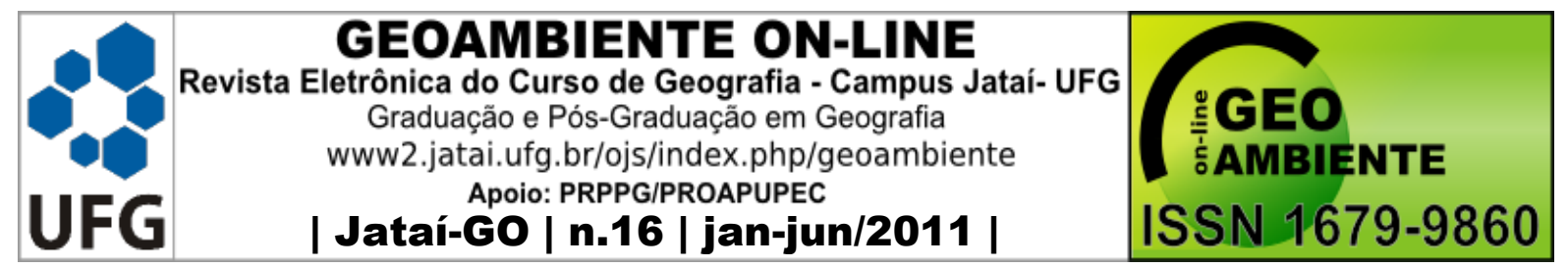

a importância de áreas verdes, pois entre as modificações que o homem produz no meio ambiente, a mais drástica e visível é a substituição das áreas verdes. E são justamente as áreas verdes que exercem influência no clima local, regional e global.

Assim nota-se que a qualidade de vida humana está relacionada à interferência do homem no meio ambiente, por causa do processo de urbanização. Neste sentido o objetivo do artigo é comparar os dados climatológicos coletados nos bairros Duque de Caxias e dos Bandeirantes, localizados em Cuiabá - MT.

\section{2 - Urbanização e Clima}

A literatura especializada vem comprovando que o homem influencia o clima através de suas atividades na escala local. Ayoade (1991), por exemplo, avalia que isso ocorre devido ao aumento populacional e das capacidades tecnológico/científicas. Para o autor, estas seriam ações e atividades humanas que agem sobre o clima: a urbanização, a industrialização, o desmatamento, a agropecuária, a drenagem, a construção de lagos artificiais etc. Porém, um dos maiores impactos acontece nas áreas urbanas, onde o clima difere sobremaneira daquele encontrado nas áreas rurais circundantes.

Tavares (2002) declara que o processo de urbanização, conduzido pelo homem, é o principal agente modificador do ambiente e que as transformações na superfície tornam o clima, uma das variáveis mais importantes do meio natural, mais vulnerável, sofrendo sérios impactos. Dessa forma, as características climáticas da cidade são alteradas em micro e meso escalas, de modo geral elevando o calor e a precipitação pluviométrica, bem como alterando o fluxo de ventos e a umidade relativa do ar.

Brandão (2003) observa que, na cidade, o ritmo e a intensidade da produção e armazenamento de calor são fortemente diferentes dos que ocorrem na zona rural, em razão da presença das indústrias, dos veículos, da substituição da cobertura vegetal por construções (cimento, concreto e alvenaria), da pavimentação asfáltica, das modificações na topografia etc.

Essas interferências, segundo Cabral (1997 apud SANTOS, 2002), realmente afetam diariamente o balanço de energia entre a superfície e a atmosfera local, provocando alterações climáticas que se propagam na temperatura, na precipitação pluviométrica, na umidade do ar, na direção e na velocidade dos ventos, além de outros problemas. 


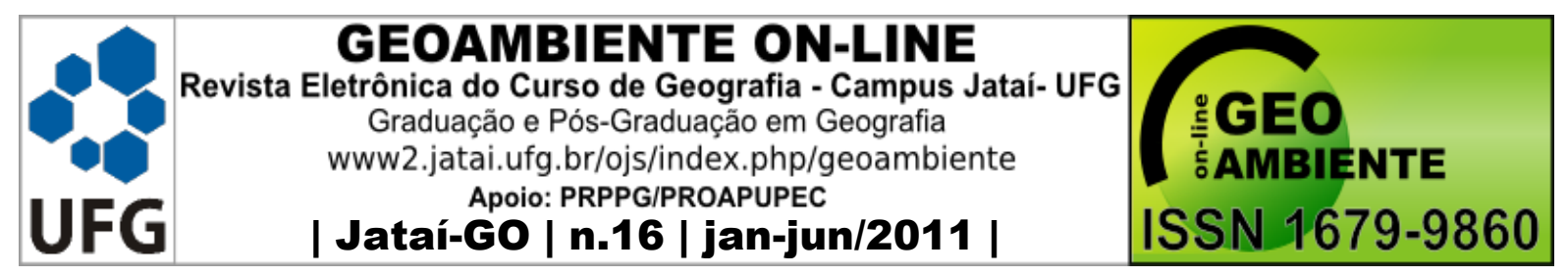

Sant'Anna Neto (2000) adverte que o aumento da temperatura, por exemplo, e a verticalização das construções cria um "labirinto de refletores", ou seja, a energia solar passa a refletir-se nos edifícios, aquecendo o ar. Ademais, a evaporação diminui, por causa da redução das áreas verdes e da canalização dos rios e córregos, além da captura das águas pluviais, implicando a diminuição da capacidade da atmosfera de resfriar o ar.

Complementando essas constatações, Costa (1999) anuncia que a ação antrópica modifica o balanço de radiação da superfície, ou seja, a substituição do meio natural pelo ambiente urbanizado provoca mudanças nos processos de absorção, transmissão e reflexão, de sorte que o clima adquire características específicas.

Nesse sentido, Ruoso et al. (2006) concluem que os elementos climáticos, como a precipitação, o vento, a temperatura, a umidade do ar e a pressão, são capazes de responder de formas diferentes à circulação atmosférica regional, de acordo com os fatores geográficos locais. Assim, o clima de determinado lugar pode apresentar alterações de caráter particular, resultantes da disposição de fatores próprios da região, como o relevo, os rios, a vegetação, as edificações etc., os quais interferem no balanço térmico local.

Diante do exposto, confirma-se que a urbanização altera o balanço de energia. De fato, como analisa Sant'Anna Neto (2000), as condições climáticas, ou melhor, a temperatura é maior e a umidade relativa do ar é menor nas grandes áreas fortemente urbanizadas do que nas áreas rurais circunvizinhas, formando o que se convencionou chamar ilha de calor.

Sobre esse mesmo assunto, Ayoade (1991) sustenta que outras consequências da ação do homem no clima, além da redução da umidade relativa do ar e do aumento da temperatura e da precipitação pluviométrica, são os nevoeiros e neblinas, que se tornam mais espessos, mais frequentes e duradouros, e os ventos, que podem se tornar fracos ou fortes ao circular pelas áreas urbanas.

Como se vê, diversas pesquisas têm sido realizadas para analisar se a presença ou ausência da vegetação pode influenciar as condições climáticas. Sellers (1987 apud ZAMPARONI, 2000), por exemplo, observa que um ponto comum abordado pelos estudiosos é a importância da relação entre atmosfera e vegetação, sendo esta última apresentada como um fator de peso que influencia as trocas de radiação e calor, nas escalas local e, consequentemente, regional.

De acordo com Perez et al. (2001 apud COLTRI, 2006), as plantas, durante a evapotranspiração, liberam o vapor d'água, que, consequentemente, eleva a umidade relativa 


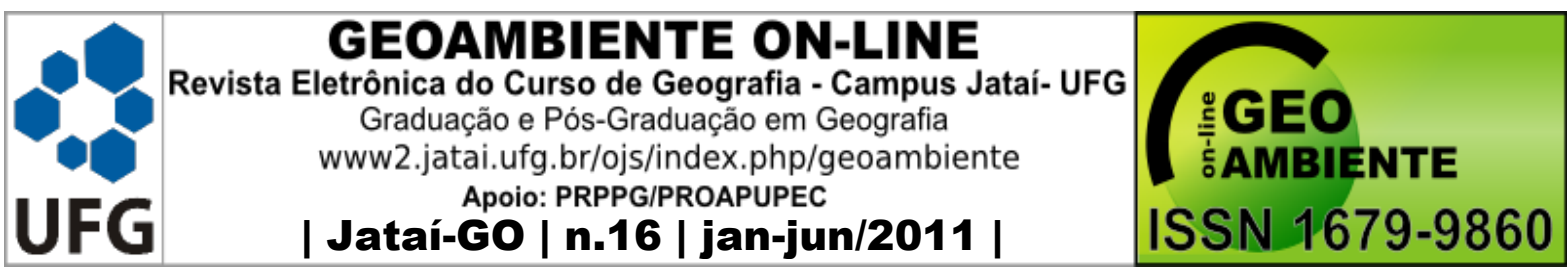

e reduz a temperatura do ar. Jones et al. (1990 apud COLTRI, op. cit.) acrescenta que a liberação desse vapor produz uma perda de calor que varia de 24.5 a $29.5 \mathrm{MJ} / \mathrm{m}^{2}$, em locais de clima árido e úmido, e, em ambientes de clima temperado, varia entre 0.7 a $7.4 \mathrm{MJ} / \mathrm{m}^{2}$. Ainda, Coltri (op. cit.) explica que a dissipação de energia existente refere-se à quantidade de água que evapora da superfície, adaptando o fluxo de calor sensível.

As copas das árvores constituem sua parte mais aquecida num dia de verão: a superfície da copa é a mais efetiva superfície radiante, por ser a parte exposta diretamente para o céu. O calor irradiado pelas camadas mais baixas da floresta é captado pelo solo. Como as copas perdem seu calor rapidamente, elas se tornam a parte mais fria das árvores. $\mathrm{O}$ ar nas copas esfria, torna-se mais denso e desce em direção ao solo. $\mathrm{O}$ ar das copas aquece-se rapidamente, e assim, durante a noite, as temperaturas entre as copas e o solo são quase uniformes.

$\mathrm{Na}$ ausência de ventos com velocidade média ou alta afirma que o solo não aquecido das áreas sombreadas absorve o calor do ar mais rapidamente do que o calor transmitido por convecção ou condução nas áreas não sombreadas. A alta umidade do ar embaixo das árvores aumenta a quantidade de calor necessária para fazer crescer a temperatura do ar. Por essa razão, pode-se afirmar que as plantas amenizam as temperaturas máximas do ar e do solo. (ROBINETTE, 1972 apud CARVALHO, 2001, p. 126-128).

Segundo Oliveira (1996) as funções da vegetação urbana e suas implicações ecológicas e sociais podem ser verificadas no quadro 1:

\begin{tabular}{|c|c|c|}
\hline Funções & Implicações Ecológicas & Implicações Sociais \\
\hline $\begin{array}{l}\text { - Interceptação, absorção e } \\
\text { reflexão de radiação luminosa } \\
\text { - Fotossíntese, Produção Primária } \\
\text { Líquida } \\
\text { - Fluxo de energia }\end{array}$ & $\begin{array}{l}\text { - Manutenção do equilíbrio dos } \\
\text { ciclos biogeoquímicos } \\
\text { - Manutenção das altas taxas de } \\
\text { evapotranspiração } \\
\text { - Manutenção do micro clima } \\
\text { - Manutenção da fauna }\end{array}$ & $\begin{array}{l}\text { - Conforto térmico } \\
\text { - Conforto lúmnico } \\
\text { - Conforto sonoro } \\
\text { - Manutenção da biomassa com } \\
\text { possibilidade de integração da } \\
\text { comunidade local }\end{array}$ \\
\hline - Biofiltração & $\begin{array}{l}\text { - Eliminação de materiais tóxicos } \\
\text { particulados e } \\
\text { incorporação } \\
\text { biogeoquímicos }\end{array}$ & $\begin{array}{l}\text { - Melhoria na qualidade do ar da } \\
\text { água de escoamento superficial }\end{array}$ \\
\hline - Contenção do processo erosivo & $\begin{array}{l}\text { - Economia de nutrientes e solos } \\
\text { - Favorecimento do processo } \\
\text { sucessional }\end{array}$ & $\begin{array}{l}\text { - Prevenção de deslizamentos, } \\
\text { voçorocas, ravinamento e perda de } \\
\text { solos } \\
\text { - Preservação dos recursos hídricos } \\
\text { para abastecimento e recreação }\end{array}$ \\
\hline - Infiltração de água pluvial & $\begin{array}{l}\text { - Redução do escoamento } \\
\text { superficial } \\
\text { - Recarga de aqüífero } \\
\text { - Diminuição na amplitude das } \\
\text { hidrógrafas }\end{array}$ & - Prevenção de inundações \\
\hline
\end{tabular}




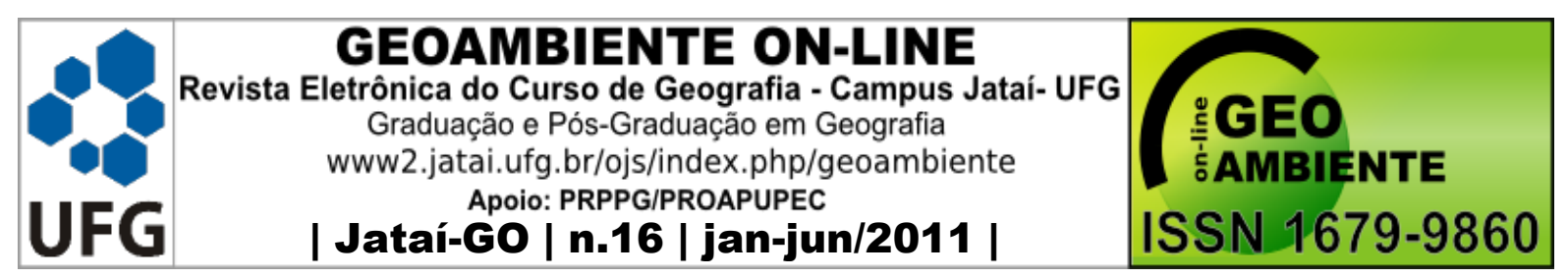

\begin{tabular}{|l|l|l|}
\hline - Movimentos de massas de ar & - Manutenção do clima & $\begin{array}{l}\text { - Conforto térmico e difusão de } \\
\text { gases tóxicos e material particulado } \\
\text { do ar }\end{array}$ \\
\hline $\begin{array}{l}\text { - Fluxo de organismos entre } \\
\text { fragmentos rurais e o meio urbano }\end{array}$ & $\begin{array}{l}\text { - Manutenção da diversidade } \\
\text { genética }\end{array}$ & $\begin{array}{l}\text { - Aumento na riqueza da flora e da } \\
\text { fauna } \\
\text { - Realce na biofilia }\end{array}$ \\
\hline - Atenuação sonora & - Aspectos etológicos da fauna & - Conforto acústico \\
\hline
\end{tabular}

Quadro 1. Funções da arborização urbana e suas implicações ecológicas e sociais.

Fonte: Oliveira, 1996.

As áreas verdes possuem importância para o clima, tanto que alguns pesquisadores as denominam ilhas de frescor. Segundo Silva; Colesante (2000 apud GOMES; SOARES, 2003) os parques urbanos têm como uma de suas características principais a qualidade ambiental, sendo essenciais ao conforto térmico, por atuar como ilhas de frescor para os bairros vizinhos.

García (1999) explicita em seu estudo que a vegetação suaviza a temperatura e a intensidade das ilhas de calor, além de aumentar a umidade do ar, pois as copas das árvores protegem a superfície ensombrada da radiação solar direta. Portanto, quando se fala de grandes áreas verdes urbanas ou de parques e jardins urbanos, o fenômeno fica bem aparente, já que nesses espaços as temperaturas são menores se comparadas às registradas nos arredores urbanos edificados. Tanto que se pode falar das ilhotas ou ilhas de frescor dentro do microclima urbano. Assim, nesses parques as temperaturas são mais baixas, e a umidade relativa do ar e produção de oxigênio são maiores.

O estudioso também afirma que se pode sentir o efeito dos parques na diminuição da temperatura urbana quando o tempo apresenta ventos fracos ou na calmaria, bem como em noites com céu limpo ou com pouca nebulosidade, e quando a ilha de calor está bem desenvolvida. Nesse momento, o gradiente de temperatura entre o parque e os arredores é capaz de provocar uma ligeira brisa (que para alguns autores são chamadas de brisas de parque). Logo, com ventos fracos ou moderados, o alcance do parque pode chegar a algumas centenas de metros fora de seus limites, de modo que, caso acompanhe a direção dominante do vento, provoca línguas de ar fresco que se desdobram pelos bairros circunvizinhos.

Assim pode-se perceber a importância da vegetação, tanto que algumas cidades têm levado em consideração este fator no planejamento.

Lombardo (1985), refletindo sobre a expansão urbana da cidade, lembra o caráter de essencialidade quanto uma legislação de uso do solo em que seja obrigatória a reserva de 


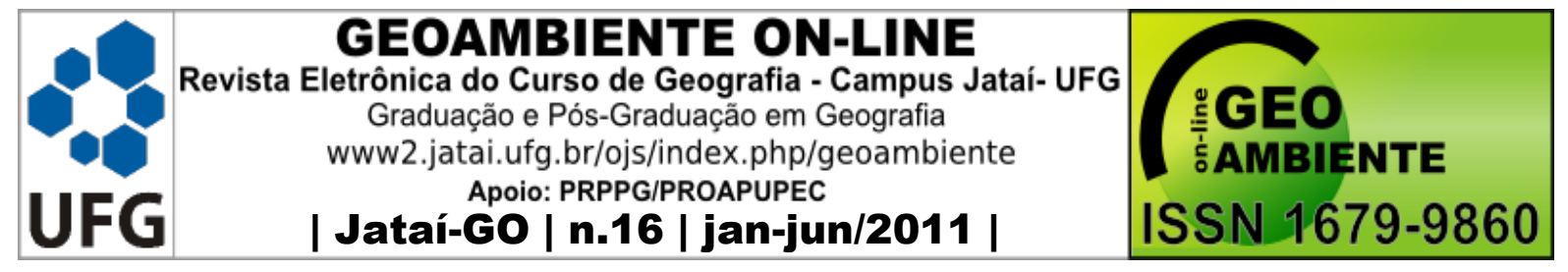

espaços verdes em todos os bairros (classes pobre e rica), principalmente nos locais onde haja pouca vegetação, para amenizar a variação de temperatura na cidade.

Neste sentido a qualidade do meio ambiente interfere na nossa própria qualidade de vida. Loboda; De Angelis (2005) concebem que a qualidade de vida urbana está diretamente ligada a diversos fatores, como a infraestrutura, o desenvolvimento econômico-social e a questão ambiental. Neste caso, as áreas verdes públicas possuem componentes essenciais para o bem-estar da população, em cuja saúde física e mental interferem diretamente.

\section{3 - Procedimentos Metodológicos}

Foram comparados os dados climatológicos coletados pelas estações climatológicas (Modelo: Davis Weather Monitor II), instaladas, conforme figura 1, nos bairros Duque de Caxias, nas coordenadas geográficas $15^{\circ} 35^{\prime} 37,9^{\prime \prime}$ de latitude sul e 56 $06^{\prime} 40,1^{\prime \prime}$ longitude oeste, a altitude do terreno é de 193m, e outra no bairro dos Bandeirantes, localizada nas coordenadas $15^{\circ} 36^{\prime} 1,2^{\prime \prime} \mathrm{S}$ e $56^{\circ} 5^{\prime} 29,6^{\prime} \mathrm{O}$, altitude do terreno de $218 \mathrm{~m}$.

Desta forma, foram analisadas a temperatura média do ar, umidade relativa média do ar, (média diária), frequiência da direção do vento, precipitação total diária, fornecidas pelas estações climatológicas, durante uma semana no mês de janeiro de 2007 (estação chuvosa) e uma semana no mês de julho de 2007 (estação seca).

Para complementar o estudo foi analisada a circulação atmosférica regional por meio de informações fornecidas por imagens de satélites - GOES 10 e cartas sinóticas do Instituto Nacional de Pesquisas Espaciais (INPE). 


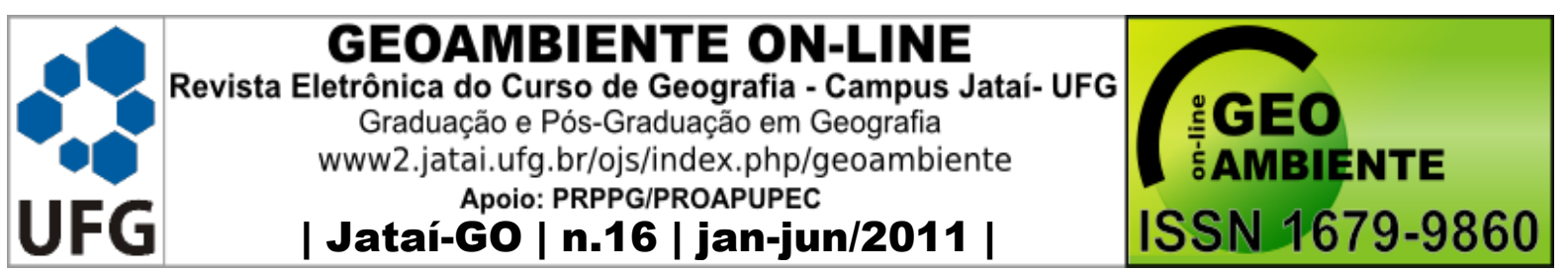

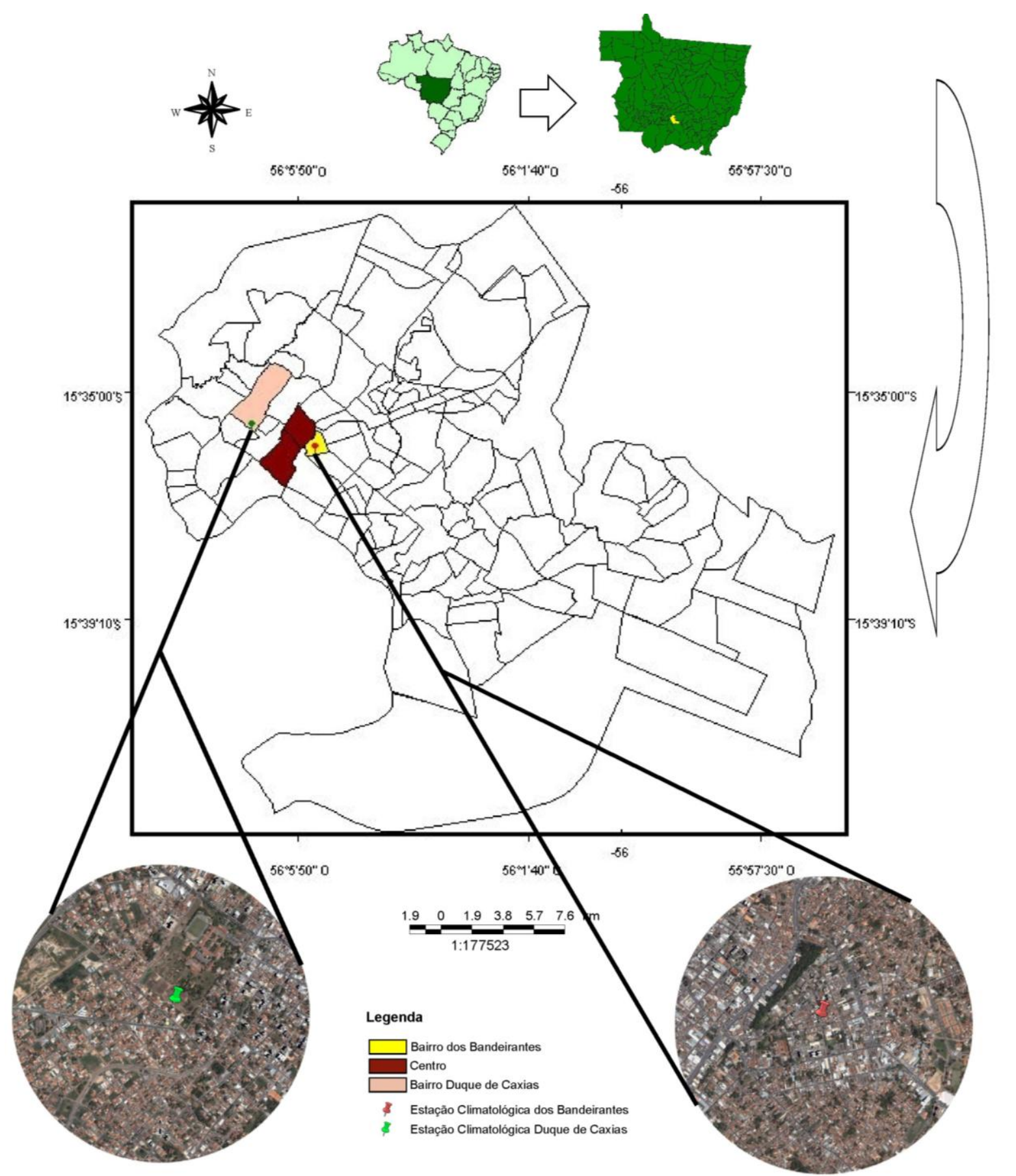

Figura 1. Mapa de localização das Estações Climatológicas Duque de Caxias e dos Bandeirantes.

4 - Dados Comparativos entre a Estação Climatológica Duque de Caxias e dos

\section{Bandeirantes}

A estação climatológica localizada no Bairro dos Bandeirantes está a aproximadamente 400 metros do Centro Principal da cidade, instalada num bairro com 


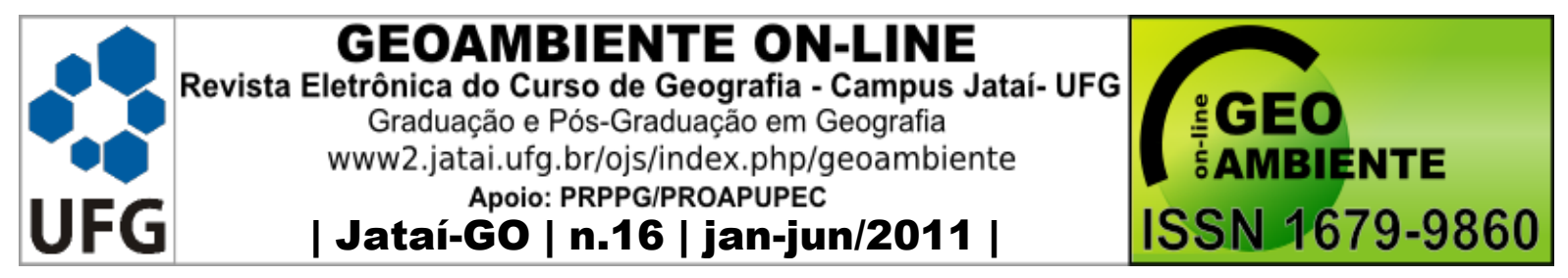

presença de prédios, residências, área comercial com escritórios (de advogados, consultórios médicos, arquitetos), escola pública (Escola Estadual Nilo Póvoas), Pronto Socorro Municipal e Santa Casa, além disso, o bairro limita-se com a Rua Clóvis Hungueney e com as avenidas: Tenente Coronel Duarte, Coronel Escolástico e General Valle, onde há grande circulação de pessoas e veículos.

A estação Duque de Caxias está instalada numa área pouco urbanizada, não possui edifícios próximos ao local, é uma área onde predominam residências, além de estar próximo ao Parque Mãe Bonifácia, a aproximadamente $1,2 \mathrm{Km}$ de distância, próxima ao $44^{\circ}$ Batalhão de Infantaria Motorizado - Batalhão Laguna, que possui uma área de aproximadamente $0,31 \mathrm{~km}^{2}$ que não é densamente construída. Também, próximo à estação climatológica encontra-se a Mata Ciliar do Ribeirão da Ponte e o Centro de Zoonoses. É importante ressaltar que no bairro onde foi instalada a estação (Duque de Caxias) e nos bairros próximos como Jardim Cuiabá e Santa Rosa existem grandes quantidades de terrenos vazios.

\subsection{Estação Chuvosa}

$\mathrm{Na}$ estação chuvosa foram analisados os dias de 15 a 21 de janeiro de 2007 . Ressaltase que durante este período atuou os seguintes Sistemas Atmosféricos: 14 a 16 - Zona de Convergência do Atlântico do Sul, 17 a 18 - Massa Equatorial Continental, 19 a 21 - Massa Tropical Continental.

Desta forma conforme a figura 2, durante esta semana a temperatura média na Estação dos Bandeirantes foi de $28,5^{\circ} \mathrm{C}$ e na Estação Duque de Caxias, foi de $27,8^{\circ} \mathrm{C}$. Assim a dos Bandeirantes teve uma diferença de temperatura, de $0,7^{\circ} \mathrm{C}$ maior que a Duque de Caxias. Quando analisadas as médias diárias dos Bandeirantes registrou as maiores temperaturas, a maior diferença foi encontrada no dia $19: 1,1^{\circ} \mathrm{C}$, já a menor diferença foi no dia $21: 0,1^{\circ} \mathrm{C}$. 

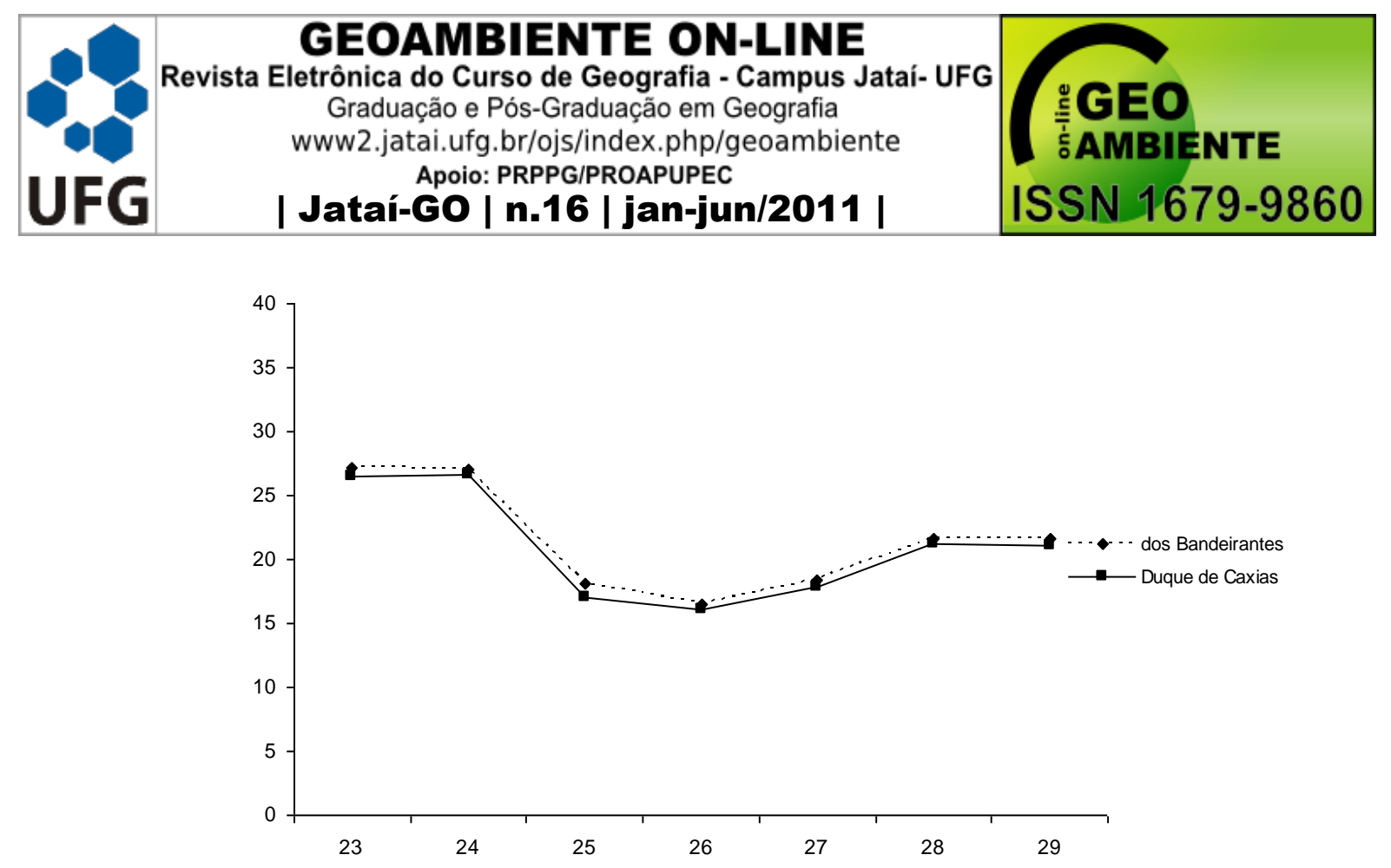

Figura 2. Temperatura média do ar durante uma semana no mês de janeiro de 2007 das Estações Duque de Caxias e dos Bandeirantes.

Em relação à umidade relativa do ar, de acordo com a figura 3, a média na Estação dos Bandeirantes durante esta semana foi de 73,4\%. Já na Estação Duque de Caxias, foi de 78,4\%. Assim a dos Bandeirantes teve uma diferença no valor menor em $5 \%$ em relação a Duque de Caxias. Quando analisados as médias diárias a Estação dos Bandeirantes registrou as menores taxas de umidade relativa do ar do que a Duque de Caxias em todos os dias analisados. A maior diferença foi encontrada no dia 19 , no valor de $6,8 \%$, já a menor taxa foi no dia 21 , com $2,5 \%$.

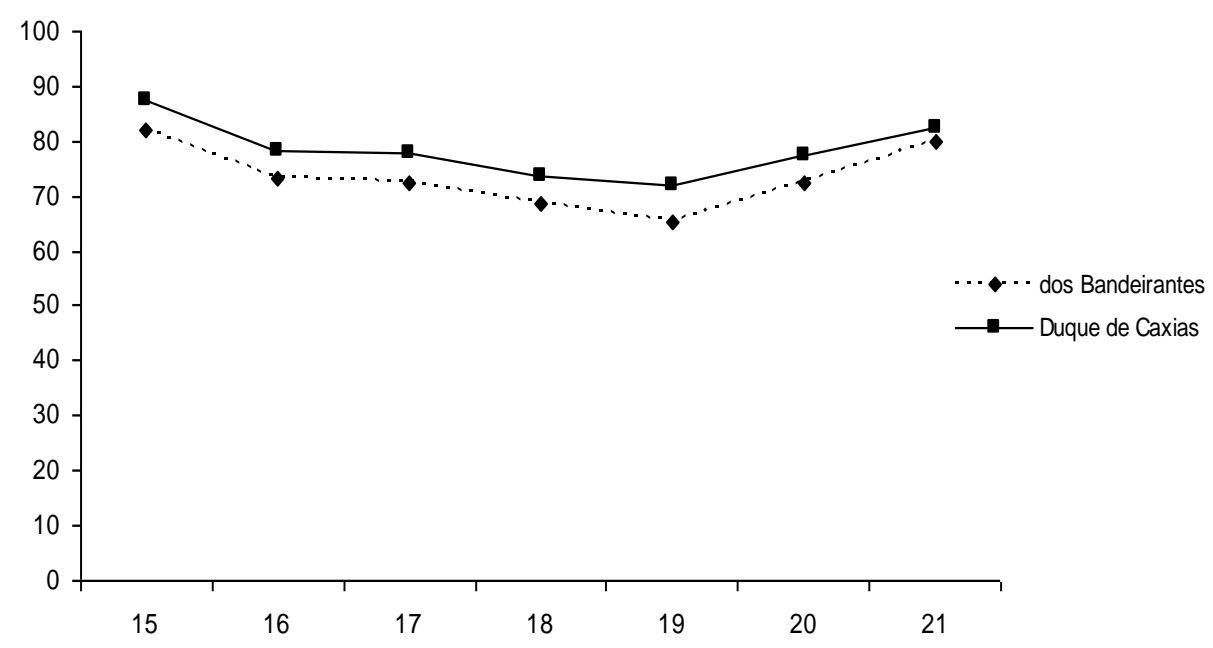

Figura 3. Umidade relativa média do ar durante uma semana no mês de janeiro de 2007 das Estações Duque de Caxias e dos Bandeirantes. 


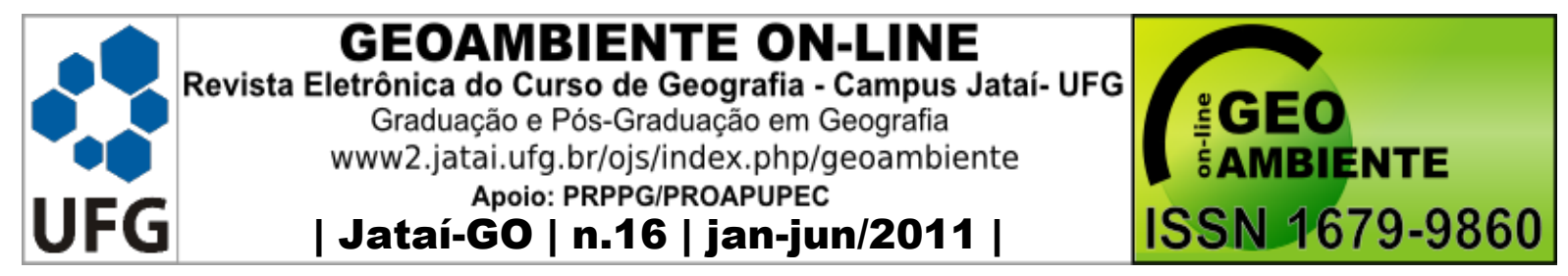

Conforme a figura 4 as diferenças do dia 19, de temperatura e umidade do ar, são explicadas, devido ao fato de não ter havido precipitação no dia 19 e no dia anterior. Já as diferenças do dia 21, são devido à precipitação, inclusive foi a maior taxa registrada no mês, dos Bandeirantes: 114,6mm e na Duque de Caxias 65,6mm.

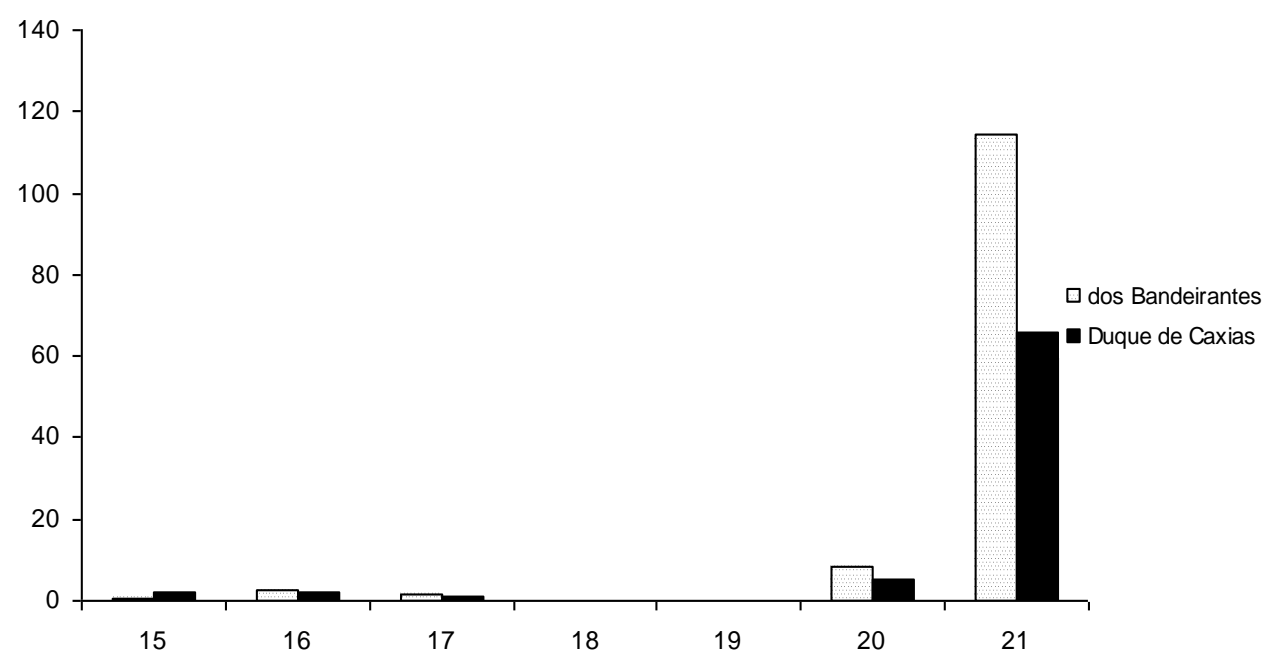

Figura 4. Precipitação total durante uma semana no mês de janeiro de 2007 das Estações Duque de Caxias e dos Bandeirantes.

Em relação à direção do vento verifica-se através da figura 5 uma predominância em ambas as estações climatológicas do quadrante: norte/oeste, ambas estações com $69 \%$.

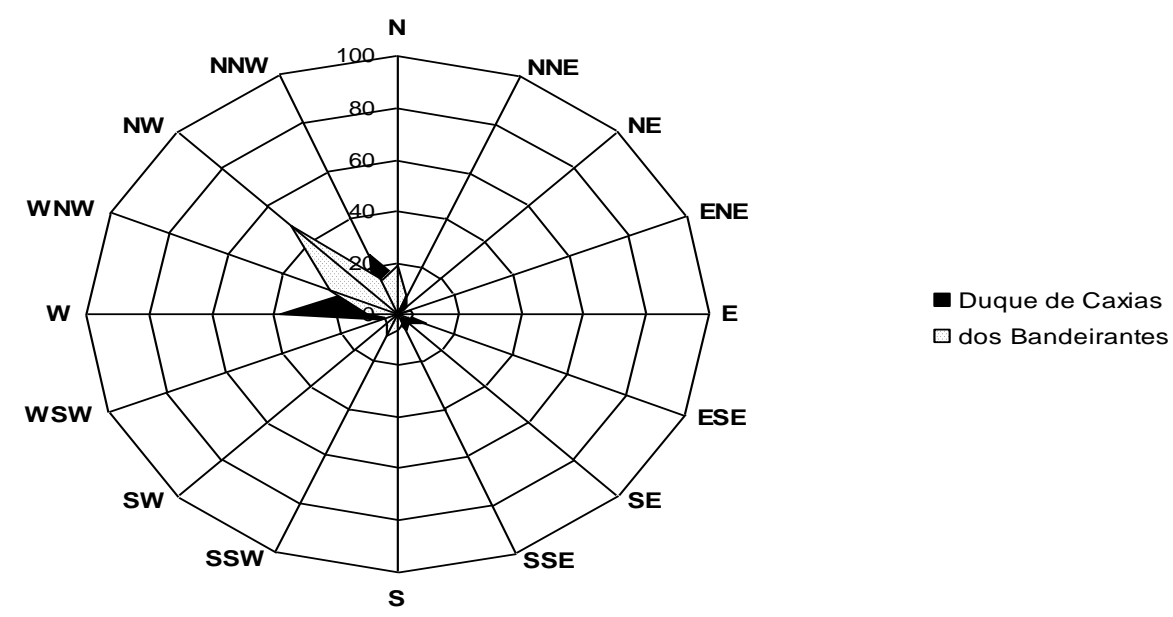

Figura 5. Freqüência da direção do vento durante uma semana no mês de janeiro de 2007 das Estações Duque de Caxias e dos Bandeirantes.

\subsection{Estação Seca}




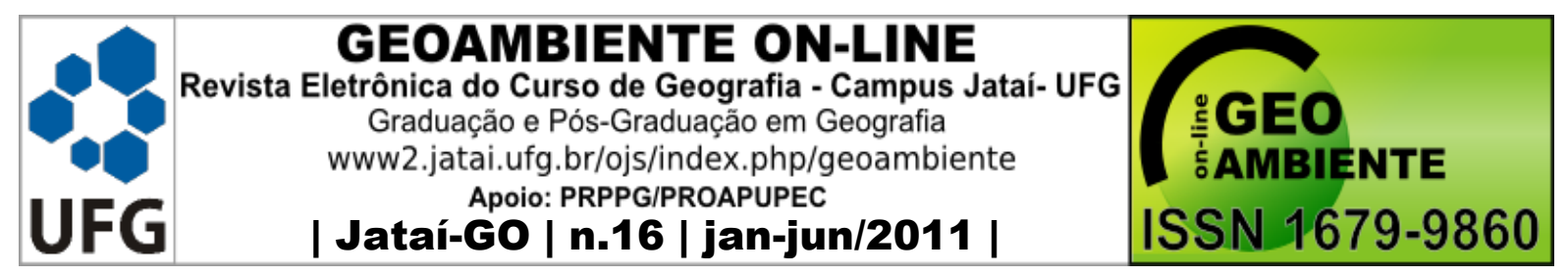

$\mathrm{Na}$ estação seca foram analisados os dias de 23 a 29 de julho de 2007. Ressalta-se que durante este período atuou os seguintes Sistemas Atmosféricos: 23 - Frente Fria, 24 Frente Estacionária, 25 - Frente Fria, 26 a 28 - Frente Estacionária, 29 - Massa Polar Atlântica.

Conforme a figura 6, durante esta semana, a temperatura média na Estação dos Bandeirantes foi de $21,5^{\circ} \mathrm{C}$. Já na Estação Duque de Caxias, a temperatura média do período foi de $20,9^{\circ} \mathrm{C}$. Assim a dos Bandeirantes teve uma diferença maior de temperatura no valor de 0, $6^{\circ} \mathrm{C}$, em relação a Duque de Caxias. Quando analisadas as médias diárias a Estação dos Bandeirantes registrou maiores temperaturas do que a Duque de Caxias em todos os dias analisados. A maior diferença na temperatura foi encontrada no dia 25 , diferença de $1,1^{\circ} \mathrm{C}$, já a menor taxa foi no dia 28 , temperatura: $0,3^{\circ} \mathrm{C}$.

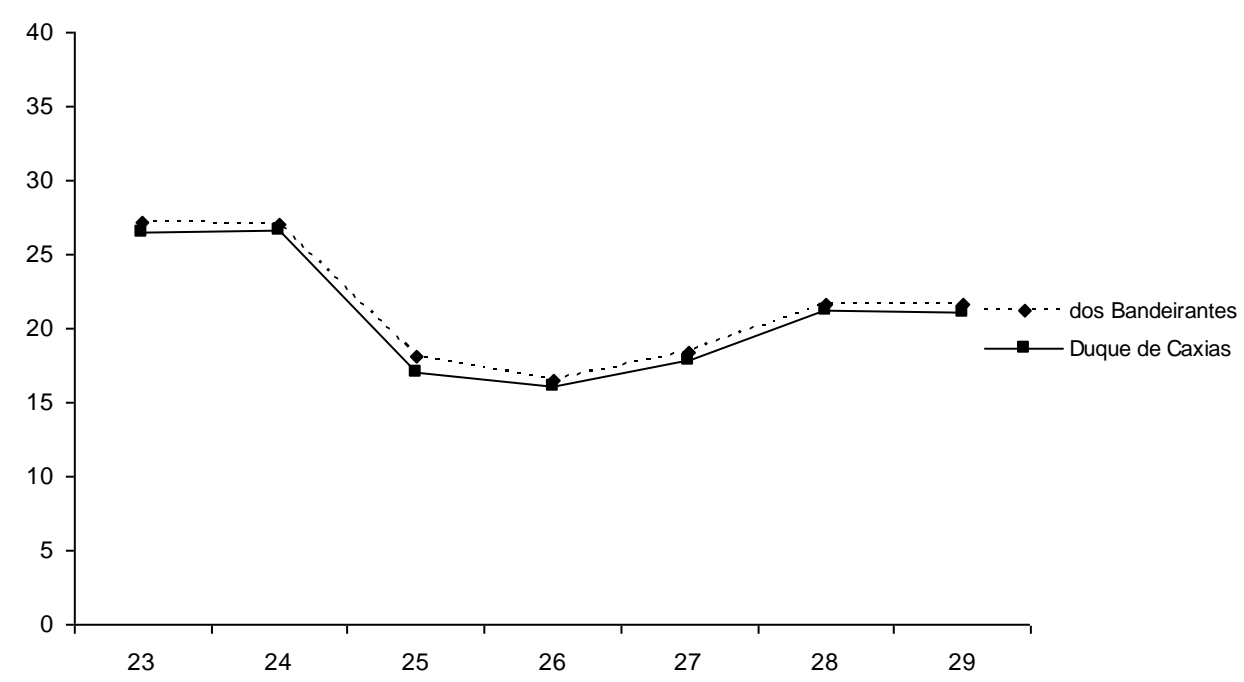

Figura 6. Temperatura média do ar durante uma semana no mês de julho de 2007 das Estações Duque de Caxias e dos Bandeirantes.

Em relação à umidade relativa do ar, de acordo com a figura 7, durante esta semana a média na Estação dos Bandeirantes foi 60,3\%. Já na Estação Duque de Caxias, a média do período foi $63,7 \%$. Assim a dos Bandeirantes teve uma diferença menor no valor de 3,4\% em relação a Duque de Caxias. Quando analisadas as médias diárias, a Estação dos Bandeirantes registrou as menores taxas de umidade relativa do ar do que a Duque de Caxias em todos os dias analisados. A maior diferença ocorreu no dia 27 , no valor de $4 \%$, já a menor diferença foi no dia 28 , com $1,7 \%$. 

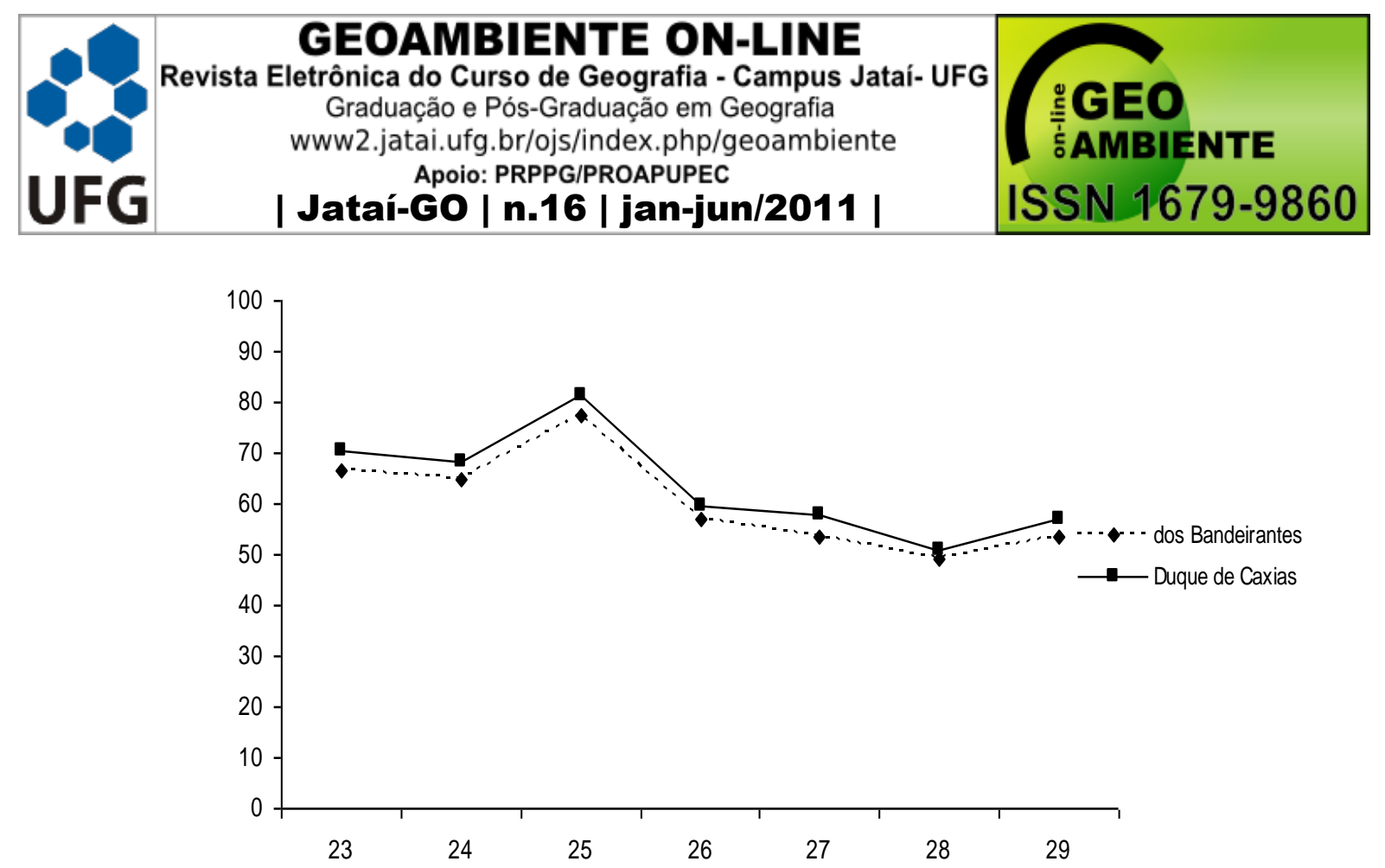

Figura 7. Umidade relativa média do ar durante uma semana no mês de julho de 2007 das Estações Duque de Caxias e dos Bandeirantes.

Conforme figura 8 , no dia 25 foi registrada a única precipitação da semana analisada, dos Bandeirantes: 13,6mm e Duque de Caxias: 11,4mm. Assim a precipitação em conjunto com a Frente Estacionária ajudou a diminuir as diferença da temperatura e umidade relativa nestes dias.

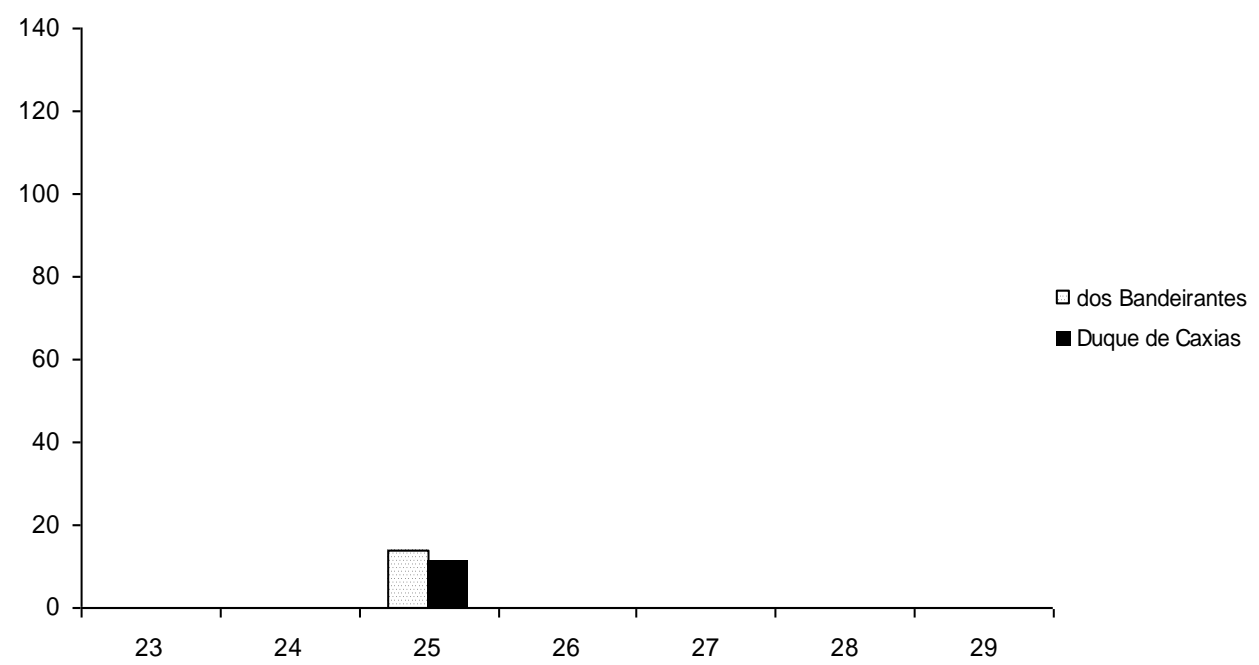

Figura 8. Precipitação total durante uma semana no mês de julho de 2007 das Estações Duque de Caxias e dos Bandeirantes.

Em relação à direção do vento, verifica-se através da figura 9 a predominância em ambas as estações climatológicas do quadrante: sul/leste, na Duque de Caxias - 77\% e na dos Bandeirantes $-64 \%$. 


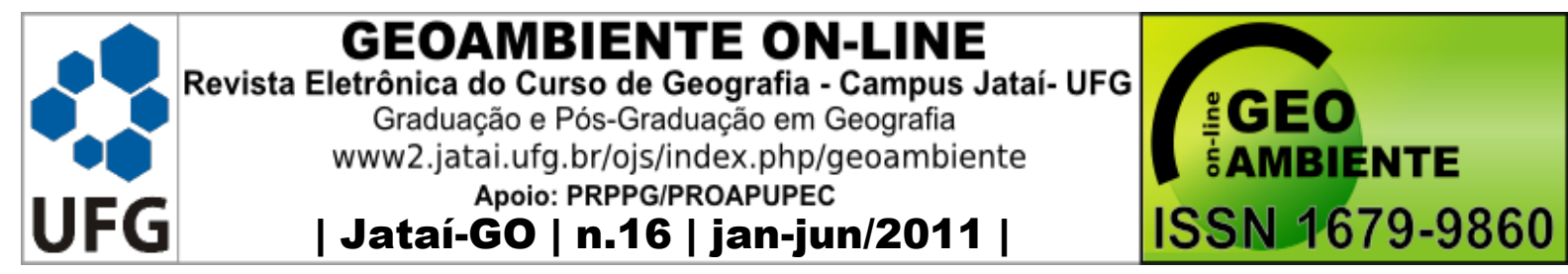

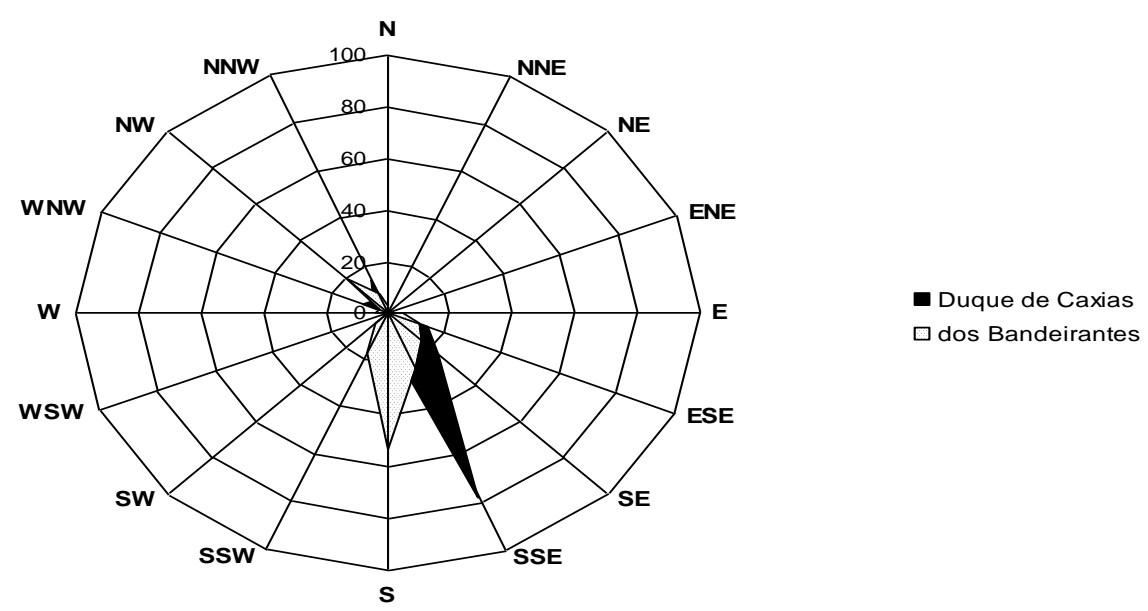

Figura 9. Freqüência da direção do vento durante uma semana no mês de julho de 2007 das Estações Duque de Caxias e dos Bandeirantes.

Desta forma os dados apresentam algumas diferenças na estação chuvosa de: temperatura $-0,6^{\circ} \mathrm{C}$, umidade $-3,4 \%$, já na estação seca: temperatura $-0,7^{\circ} \mathrm{C}$, umidade $5,3 \%$. Essa pequena diferença pode ser explicada, pois entre o centro principal e o bairro dos Bandeirantes está situado o Parque Antônio Pires de Campos (Morro da Luz) a uma distância de aproximadamente $300 \mathrm{~m}$ da estação, o que ajuda a amenizar a temperatura e elevar a umidade do ar proveniente do centro. Além disso, a estação dos Bandeirantes está localizada numa altitude superior (possui $218 \mathrm{~m}$ ) não só em relação ao centro da cidade (que está numa baixada) como da estação Duque de Caxias, com 193m.

Portanto, através dos dados analisados, percebe-se que apesar da distância entre as duas estações ser de aproximadamente $2,3 \mathrm{~km}$, existe diferença nos valores analisados durante um mesmo período, assim o que provavelmente interferiu nos dados foi o grau de urbanização em torno das estações climatológicas.

\section{5 - Considerações Finais}

Através da comparação entre os resultados obtidos entre as duas estações climatológicas, observou-se que a estação Duque de Caxias por encontrar-se instalada numa área pouco urbanizada, onde predominam residências, mas próxima a áreas verdes, como do Parque Mãe Bonifácia, da Mata Ciliar do Ribeirão da Ponte e do Centro de Zoonoses, recebe influencia no comportamento das médias da temperatura e a umidade relativa do ar registradas naquele local. 


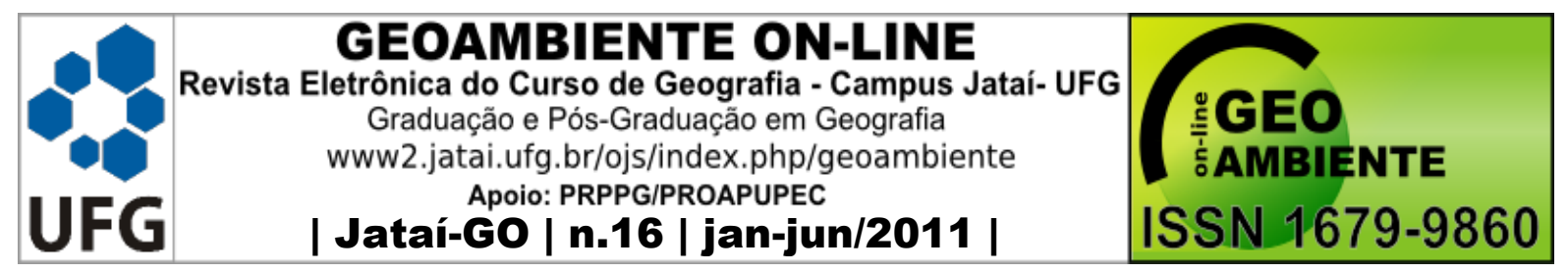

Já a estação dos Bandeirantes, apesar de não estar instalada no centro principal da cidade, e sim num bairro onde se mescla o residencial, o comercial e a verticalização, além de estar próxima a avenidas de grande circulação de veículos, obteve maiores valores de médias de temperatura do ar e menores de umidade relativa do ar, em comparação a outra estação climatológica, durante o período analisado.

Dessa forma, percebe-se a importância de áreas verdes, assim não se pode deixar de lembrar que alguns trabalhos publicados no início da década de 1990, como Guarim Neto (coord.) (1990) alertava os cuidados na expansão urbana. Muito mudou nestes 20 anos, áreas antes livres, hoje têm construção, a verticalização na cidade cresceu, novas áreas estão sendo abertas na cidade, entre outros problemas urbanos. Atualmente uma das áreas em crescimento de Cuiabá é a região oeste, que ainda possui grandes áreas verdes e está abrindo terrenos para construção de condomínios (horizontais e verticais) não só para a classe alta como para classes médias e baixas.

Desta forma pode-se identificar que todos nós, sociedade e governo, temos responsabilidade com relação à problemática urbana tratada neste estudo. Os cidadãos, devem começar as mudanças de paradigmas nas próprias casas, como manter as árvores nos quintais, por exemplo. Além disso, devem exigir dos órgãos de planejamento das cidades que cuidem das políticas públicas que engendram o uso do solo urbano. Conservar as áreas verdes, etc. Portanto, todos devem objetivar a qualidade ambiental urbana e de vida humana.

\section{6 - Bibliografias}

AYOADE, J. O. Introdução à Climatologia para os Trópicos. 3.a ed. Rio de Janeiro: Difel, 1991.

BRANDÃO, A. M. de P. M.. O Clima Urbano na Cidade do Rio de Janeiro. In: MENDONÇA, Francisco; MONTEIRO, Carlos Augusto de Figueiredo (orgs.). Clima Urbano. São Paulo: Contexto, 2003. p. 121-153.

BUCCHERI FILHO, A. T.; NUCCI, J. C. Espaços Livres, Áreas Verdes e Cobertura Vegetal no Bairro Alto da XV, Curitiba/PR. Revista do Departamento de Geografia. São Paulo - SP, n. 18,2006 . p. $48-59$.

CARVAlhO, M. M. de. Clima Urbano e Vegetação: Estudo Analítico e Prospectivo do Parque das Dunas em Natal. Natal-RN: UFRN, 2001. Dissertação (Mestrado em Arquitetura e Urbanismo). Centro de Tecnologia, Universidade Federal do Rio Grande do Norte, 2001. 


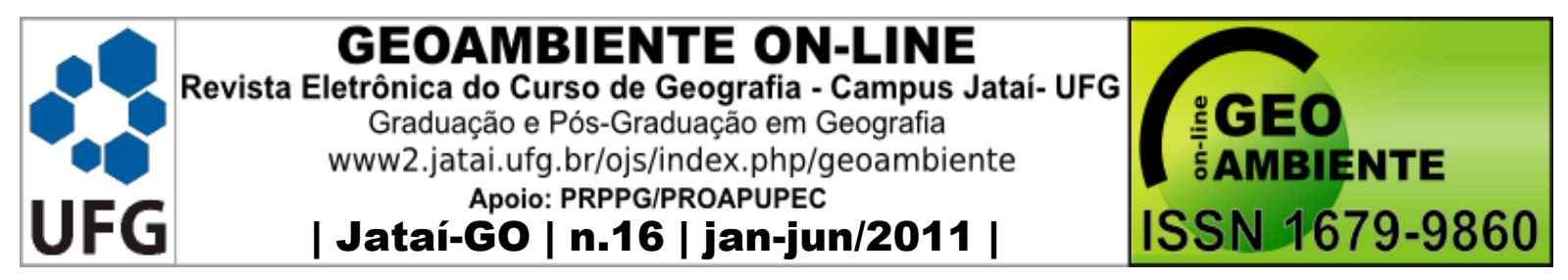

COLTRI, P. P. Influência do Uso e Cobertura do Solo no Clima de Piracicaba, São Paulo: Análise de Séries Históricas, Ilhas de Calor e Técnicas de Sensoriamento Remoto. PiracicabaSP: USP, 2006. Dissertação (Mestrado em Agronomia). Escola Superior de Agricultura "Luiz de Queiroz", Universidade de São Paulo, 2006.

COSTA, J. E. F. M. da. Estudo da Influência da Área Verde no Clima Urbano: O Caso do Parque Mãe Bonifácia, em Cuiabá - MT. Cuiabá-MT: UFMT, 1999. Monografia (Bacharelado em Geografia). Instituto de Ciências Humanas e Sociais, Universidade Federal de Mato Grosso, 1999.

GARCÍA, M. C. M. Climatologia Urbana. Barcelona: Universitat de Barcelona, 1999. (Textos Docentes, 160).

GOMES, M. A. S.; SOARES, B. R.. A Vegetação nos Centros Urbanos: Considerações sobre os Espaços Verdes em Cidades Médias Brasileiras. Estudos Geográficos. Rio Claro - SP, vol. 01, n. 01, p. 19-29, jun. 2003.

LOBODA, C. R.; DE ANGELIS, B. L. D. Áreas Verdes Públicas Urbanas: Conceitos, Usos e Funções. Ambiência. Guarapuava - PR, vol. 01, n. 01, p. 125-139, jan.-jun. 2005.

LOMBARDO, M. A. Ilha de Calor nas Metrópoles: O Exemplo de São Paulo. São Paulo: Hucitec, 1985.

OLIVEIRA, C. H. de. Planejamento Ambiental na Cidade de São Carlos (SP) com Ênfase nas Áreas Públicas e Áreas Verdes: Diagnóstico e Propostas. São Carlos-SP: 1996. Dissertação (Mestrado em Ecologia e Recursos Naturais). Centro de Ciências Biológicas e da Saúde, Universidade Federal de São Carlos, 1996.

RUOSO, D. et. al. Respostas Locais à Circulação Regional em Santa Maria e Santa Cruz do Sul: Uma Análise de Normais Climatológicas de Temperatura e Precipitação. In: VII SIMPÓSIO BRASILEIRO DE CLIMATOLOGIA GEOGRÁFICA: Os Climas e a Produção do Espaço no Brasil, 2006, Rondonópolis - MT. Anais... Rondonópolis: Universidade Federal de Mato Grosso / Associação Brasileira de Climatologia, 2006.

SANT'ANNA NETO, J. L. Mudanças Climáticas Globais: Implicações no Desenvolvimento Econômico e na Dinâmica Natural. Revista Pantaneira. Aquidauana-MS: Universidade Federal de Mato Grosso do Sul - Campus de Aquidauana, v. 02, n. 02, p. 66-78, jul.-dez. 2000.

SANTOS, E. E. dos. Uso e Ocupação do Solo e Enchentes Urbanas em Área Tropical: O Exemplo de Cuiabá/MT. Cuiabá-MT: UFMT, 2002. Dissertação (Mestrado em Ecologia e 


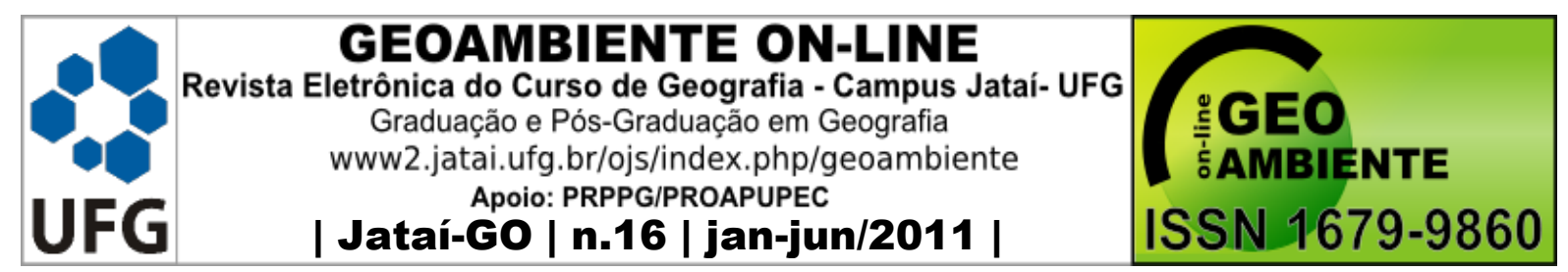

Conservação da Biodiversidade), Instituto de Biociências, Universidade Federal de Mato Grosso, 2002.

TAVARES, R. O Clima de Sorocaba-SP: Aspectos Regionais, Locais e Urbanos. In: SANT'ANNA NETO, João Lima (org.). O Clima das Cidades Brasileiras. Presidente Prudente: [s. n.], 2002.

ZAMPARONI, C. A. P. G. Desmatamento, Urbanização do Campo e Variabilidade Climática na Amazônia Mato-Grossense. São Paulo-SP: USP, 2000. Tese de Doutorado (Doutorado em Geografia Física), Departamento de Geografia, Faculdade de Filosofia, Letras e Ciências Humanas, Universidade de São Paulo, 2000. 